Kiryoku, Volume 3 No 42019

e-ISSN: 2581-0960 p-ISSN: 2599-0497

Tersedia online di http://ejournal.undip.ac.id/index.php/kiryoku

\title{
Seppuku: Kematian Terhormat Dalam Tradisi Jepang
}

\author{
Titiek Suliyati \\ Program Studi S1 Sejarah Fakultas Ilmu Budaya Universitas Diponegoro \\ E-mail : suliyati.titiek@gmail.com
}

\begin{abstract}
Abstrak
Pada zaman modern, yaitu zaman setelah Restorasi Meiji, seppuku secara bertahap menghilang seiring dihapuskannya golongan samurai. Walaupun demikian di Jepang masih ada orang yang melakukan seppuku dan harakiri, tetapi motivasi, metode pelaksanaan dan tujuannya berbeda dari seppuku dan harakiri di zaman sebelum restorasi Meiji. Perubahan dan dinamika masyarakat Jepang dalam melakukan seppuku dan harakiri sangat menarik untuk dikaji. Tujuan dari penulisan artikel ini adalah untuk mengetahui apakah ada korelasi antara tradisi seppuku dengan jumlah bunuh diri yang besar di Jepang saat ini. Untuk mengkaji korelasi tersebut penulisan artikel ini menggunakan metode kualitatif dengan pendekatan sejarah. Tahapan-tahapan penelitian sejarah dimulai dari pengumpulan data (heuristik), kritik sumber, interpretasi dan penulisan hasil penelitian dalam bentuk artikel. Analisa dilakukan dengan menggunakan metode kualitatif yang mencakup reduksi data, penyajian data, dan penarikan simpulan.Hasil penelitian menyimpulkan, bahwa tidak ada korelasi yang tegas antara tradisi seppuku di masa lalu dengan bunuh diri (jisatsu) yang banyak dilakukan masyarakat Jepang saat ini. Ada perbedaan tujuan, motivasi dan latar belakang dalam tindakan bunuh diri mereka.
\end{abstract}

Kata kunci : Seppuku, kematian, samurai, tradisi, Jepang

\begin{abstract}
In modern times, the era after the Meiji Restoration, seppuku gradually disappeared when the samurai group was abolished. Although in Japan there are still people who commit seppuku and harakiri but the motivation, implementation methods and objectives are different from seppuku and harakiri in the era before the Meiji restoration. The changes and dynamics of Japanese society in conducting seppuku and harakiri are very interesting to study. The purpose of writing this article is to find out whether there is a correlation between seppuku tradition and the number of suicides in Japan at this time. To explore this correlation, the writing of this article uses a qualitative method with a historical approach. The stages of historical research begin with data collection (heuristics), source criticism, interpretation and writing of research results in the form of articles. The analysis was performed using qualitative methods which include data reduction, data presentation, and concluding. The results of the study concluded that there is no strong correlation between seppuku traditions in the past with suicide (jisatsu) that many Japanese do today. There is a difference in purpose, motivation and background in their suicide.
\end{abstract}

Keywords : Seppuku, dead, samurai, tradition, Japan

\section{PENDAHULUAN}

Masyarakat Jepang adalah masyarakat yang unik, karena menjalankan tradisi dan budaya yang beraneka ragam. Aneka ragam budaya dan tradisi meliputi seluruh aspek dalam kehidupan manusia. Ada tradisi/ budaya yang menunjukkan rasa 
sukacita, ada dukacita, semangat dan rasa putus asa. Di Jepang tradisi seppuku dan hara-kiri yang oleh masyarakat di luar masyarakat Jepang dipandang sebagai ekspresi putus asa, sesungguhnya bukan bermakna sebagai keputusasaan. Banyaknya kasus bunuh diri di banyak negara, menyebabkan banyak penelitian dilakukan oleh para ahli unuk mengungkap apa yang menjadi latar belakang dan penyebab bunuh diri.

Beberapa kajian tentang seppuku telah dilakukan oleh beberapa penulis, yaitu antara lain Seward (1995), yang menulis buku Hara- Kiri Bunuh Diri Ala Jepang (terjemahan). Buku ini mengulas tentang tradisi harakiri yang lasim dilakukan oleh golongan samurai sejak dari zaman awal keberadaannya sampai zaman Meiji. Seward menguraikan, bahwa harakiri menjadi bagian dalam bushido, yang menuntut tanggungjawab, kesetiaan, pengabdian yang tinggi, termasuk pengorbanan jiwa. Sikap patriotisme dan kepahlawanan samurai dihargai dan dihormati ketika ia melakukan seppuku yang tujuannya untuk membela kepentingan orang banyak, seperti ketika seorang samurai dalam peperangan menyelamatkan pasukannya dengan seppuku.

Kajian yang lain adalah skripsi yang ditulis oleh Batubara (2008), yang berjudul Seppuku : Telaah Religiositas dalam Upacara Bunuh Diri Ala Jepang. Skripsi ini mengkaji tentang pengaruh agama dan kepercayan dalam seppuku. Agama dan kepercayaan yang mempengaruhi seppuku adalah Budha dari aliran zen, Shinto, Konfusius dan Tao. Pengaruh agama dan kepercayaan ini tampak pada etika, falsafah yang mendasari seppuku. dan juga pada simbolsimbol perlengkapan seppuku.

Menurut Durkheim (1979: 44), bunuh diri adalah upaya seseorang untuk mengakhiri hidupnya dengan cara menyakiti diri sendiri. Durkheim (1979) juga menyebutkan bahwa ada 3 ciri dari tindakan bunuh diri, yaitu egoistik, altrustik dan anomik. Bunuh diri yang sifatnya egoistik adalah orang yang tidak memiliki ikatan kuat dengan kelompok sosialnya, seperti dikucilkan dari keluarga, teman, tidak menikah, bercerai dan sebagainya. Ciri lain dari orang yang melakukan bunuh diri dengan kategori ini adalah sifatnya skeptis dan apatis, tidak memiliki daya juang. Bunuh diri yang sifatnya altrusistik adalah bunuh diri yang didorong oleh kesetiaan, pengabdian dan rasa hormat pada kelompok di mana individu tersebut berada, seperti agama, pendidikan, norma yang berlaku dan lain sebagainya. Individu dengan sifat seperti ini biasanya lebih mementingkan kepentingan orang lain atau kelompoknya daripada dirinya sendiri.Bunuh diri yang sifatnya anomik, yaitu dorongan untuk melakukan bunuh diri karena tidak bisa menghadapi perubahan-perubahan dalam masyarakat terkait dengan perubahan nilai dan norma serta perubahan taraf hidup dan status hidup.

Seppuku dan harakiri di Jepang ada kesamaannya dengan salah satu kategori yang dikemukakan Durkheim, yaitu bunuh diri yang sifatnya altruistik. Menurut Bellah (1992 : 79) seppuku dan harakiri terkait erat dengan kehidupan keagamaan masyarakat Jepang. Agama dalam lingkungan masyarakat Jepang menjadi dasar moral dan etika yang mendorong untuk setia dan mendahulukan kepentingan masyarakat daripada kepentingan pribadi.

Secara etimologis seppuku berasal dari kata setsu dan fuku. Setsu artinya perut dan $f u k u$ artinya merobek atau memotong. Jadi pengertian seppuku adalah merobek/memotong perut. Selain seppuku ada hara-kiri yang merupakan tindakan bunuh diri juga. Hara-kiri berasal dari 
Kiryoku, Volume 3 No 42019

e-ISSN: 2581-0960 p-ISSN: 2599-0497

Tersedia online di http://ejournal.undip.ac.id/index.php/kiryoku

kata hara yang artinya perut dan kiru yang artinya memotong atau merobek. Seppuku merupakan sebutan resmi yang lebih halus untuk menyebut bunuh diri. Harakiri merupakan sebutan bunuh diri dalam keseharian (Seward, 1995 : 1-2) .

Seppuku dan harakiri memiliki keterkaitan yang erat dengan terbentuknya golongan samurai dan bushido. Seperti makna yang tersirat pada kata samurai yaitu pelayan, maka kita memahami bahwa samurai dituntut untuk mengabdi sepanjang hayat kepada majikannya/atasannya, termasuk mengorbankan jiwanya (Suliyati, 2013). Pada perkembangannya kemudian samurai semakin menunjukkan otoritasnya sebagai kelas prajurit. Pada masa kekuasaan Tokugawa di zaman Edo samurai disebut sebagai bushi. Dalam menjalankan tugasnya para bushi ini terikat dengan etika yang disebut bushido. Etika Bushido telah mendasari seppuku sebagai ekspresi yang kuat terhadap kesetiaan, kehormatan dan harga diri.

Seppuku atau harakiri dilakukan oleh samurai didasari oleh on dan giri. On dapat diartikan sebagai pengabdian yang besar dan tanpa batas kepada penguasa, yang dalam hal ini adalah kaisar. Giri bermakna kesetiaan dan pengabdian mendalam seorang bawahan atau pengikut kepada atasan atau penguasa, yang diekpresikan dalam kematian (Benedict, 1982: 122-125).

Di dalam konsep agama secara umum tindakan bunuh diri adalah tindakan yang tidak dibenarkan dan dianggap sebagai tindakan rendah, yang merupakan dosa besar. Hal ini berbeda dengan konsep beragama masyarakat Jepang, yang memandang kematian dengan cara seppuku sebagai bentuk penghormatan, kesetiaan, pengabdian kepada negara, pimpinan, majikan, orang yang dihormati atau dicintai.
Di Jepang seppuku merupakan tindakan yang legal yang dilakukan oleh para samurai untuk menebus kesalahannya, untuk permintaan maaf atas ketidakmampuannya, untuk mempertahankan harga diri, menyelamatkan nama baik keluarga maupun kelompoknya dan sebagainya. Seppuku merupakan inti dan dasar dari bushido (Nitobe, 2001 : 4).

Pada zaman modern Jepang, yaitu zaman setelah Restorasi Meiji, seppuku berangsung-angsur mulai menghilang sejalan dengan dihapuskannya golongan samurai. Walaupun tidak dipungkiri, bahwa di Jepang masih ada seppuku dan harakiri, tetapi motivasi, cara pelaksanaan dan tujuannya berbeda dari seppuku dan harakiri di era sebelum kaisar Meiji berkuasa.

Tujuan dari penulisan artikel ini adalah untuk mengetahui perubahan dan dinamika masyarakat Jepang dalam melakukan seppuku. Selain itu juga untuk mengetahui korelasi antara seppuku yang dilakukan di masa sebelum terjadinya Restorasi Meiji, yang menjadi tonggak modernisasi Jepang, dengan bunuh diri biasa atau jisatsu yang marak dilakukan oleh orang-orang jepang di zaman modern ini.

\section{METODE}

Penelitian ini dilakukan untuk memecahkan masalah yang berkaitan dengan korelasi antara tradisi seppuku di masa lalu dengan jumlah angka bunuh diri masyarakat jepang yang saat ini yang semakin banyak.

Artikel ini disusun sebagai hasil penelitian pustaka yang menggunakan metode kualitatif dengan pendekatan sejarah. Pendekatan sejarah digunakan untuk menguraikan tahapan-tahapan mulai dari pengumpulan data (heuristik), kritik sumber, intrepretasi dan penulisan hasil 
penelitian dalam bentuk artikel (Gottschalk, 2008 ).

Penelusuran data atau (heuristik) dilakukan dengan studi pustaka, yaitu pustaka-pustaka yang terkait dengan sejarah Jepang, masyarakat Jepang, kebudayaan Jepang, seppuku dan harakiri, kepercayaan masyarakat Jepang dan sebagainya. Penelusuran data juga dilakukan melalui internet untuk mencari artikel-artikel yang terkait dengan topik dan masalah yang diteliti. Penulis tidak melakukan pencarian data melalui wawancara karena jarak geografis yang jauh serta pihak-pihak terkait yang tidak memungkinkan untuk diwawancarai.

Data dan informasi yang diperoleh dari literatur kemudian dibandingkan untuk mencari kredibilitasnya. Selanjutnya informasi-informasi tersebut diinterpretasikan dan dianalisa, dicari relevansinya.

Analisa dilakukan dengan menggunakan metode kualitatif yang mencakup reduksi data, penyajian data, dan penarikan simpulan (Miles dan Huberman, 1992: 16- 19). Reduksi data yaitu menyeleksi data yang diperlukan dan sesuai dengan materi kajian. Data yang telah tersusun secara krononogis dalam hubungan sebab-akibat didiskripsikan dan disajikan dalam bentuk narasi (Louis Gottschalk, 2008). Kesimpulan dan verifikasi yaitu melakukan koreksi dan memeriksa data dari hasil-hasil studi pustaka dengan sumber-sumber data lainnya yang sejenis.

\section{HASIL DAN PEMBAHASAN}

\section{1) Awal Mula Tradisi Seppuku}

Sebelum zaman Kamakura, seppuku dan harakiri belum lazim dilakukan oleh masyarakat Jepang. Tradisi seppuku ada kaitan erat dengan tradisi samurai, yang mulai muncul pada zaman Kamakura (tahun 1192 - tahun 1333). Pada zaman Kamakura pemerintahan kekaisaran mulai melemah karena pengendali pemerintahan adalah golongan Fujiwara yang sangat kuat pengaruhnya dan otoriter, sehingga para aristokrat (keluarga kekaisaran) yang tidak mendapatkan jabatan dalam pemerintahan menyingkir ke daerah-daerah di luar kota, menjadi tuan-tuan tanah. Zaman Kamakura merupakan zaman kekacauan, karena terjadi perebutan pengaruh dan wilayah kekuasaan antara kelompok keluarga Fujiwara, Taira dan Minamoto. Untuk mengamankan wilayah dan daerah kekuasaannya, kelompok-kelompok keluarga ini merekrut pasukan pengamanan yang berasal dari masyarakat setempat, baik dari kalangan petani, masyarakat biasa dan bangsawan feodal. Perebutan pengaruh dan kekuasaan antara golongan keluarga Taira dan Minamoto sudah diawali sejak zaman sebelumnya, yaitu zaman Heian dalam pertempuran Hogen yang terjadi pada tahun 1156 dan Heiji terjadi pada tahun 1159 (Mattulada.1979 : 80).

Dua kelompok keluarga ini silih berganti memenangkan pertempuran. Kelompok keluarga yang dapat memenangkan pertempuran mendapat imbalan menjadi pembantu Kaisar dalam menjalankan pemerintahan. Pada tahun 1192 Kaisar Go-Toba mengangkat Minamoto-No Yoritomo menjadi shogun, yaitu panglima tertinggi militer/ tentara dan membangun pemerintahan keshogunan di Kamakura (Mattulada.1979 : 81). Pada dasarnya pemerintahan keshogunan merupakan pemerintahan yang dijalankan oleh golongan militer yang bersifat sangat keras dan otoriter. Dengan terbentuknya keshogunan, maka golongan militer atau samurai, berada pada strata sosial tertinggi. Sebagai pelaksana dalam pemerintahan kekaisaran Jepang, golongan samurai mendapat hak-hak istimewa dan status sosial yang tinggi.

Untuk menunjang tugas sebagai samurai diperlukan alat dan aturan-aturan yang terangkum dalam etika bushido, yang harus ditaati dan dijalankan. Etika bushido 
adalah dasar pembentukan karakter para samurai yang berkaitan dengan kehormatan, tanggungjawab, kesetiaan, kesungguhan, kedisiplinan, rasa malu, tata krama, kemurnian, kesederhanaan dan semangat juang yang tinggi (Bryant, 2004 :9-10). Watak satria yang dikembangkan dalam aktivitas samurai, yang dalam kesehariannya dituntut setia, hormat, patuh, jujur, sopan, rendah hati, adil dan berani membela majikan atau atasannya, memerlukan aturan ketat agar mereka terarah dalam menjalankan peran dan tugasnya. Kehormatan menjadi hal utama yang selalu dijaga dan diperjuangkan dalam kehidupan maupun kematian. Dalam tradisi bushido, kematian terhormat adalah melalui seppuku. Dalam melakukan seppuku diperlukan keberanian yang tinggi dan tekat yang kuat, agar tujuan dari seppuku sesuai dengan yang diharapkan.

Ajaran bushido seringkali diekspresikan oleh samurai dalam seppuku, yaitu tindakan menusuk atau merobek perut dengan pedang dengan tujuan untuk mempertahankan kehormatan atau harga diri. Seppuku bukan sekedar tindakan bunuh diri (hara-kiri) tanpa makna, tetapi merupakan tindakan mulia dan terhormat. Ketika seorang samurai tidak dapat mencapai tujuannya semasa hidup, maka ia akan memilih kematian untuk mencapai kehormatan (Suryohadiprojo, $1982: 49$ ).

Kematian terhormat bagi para samurai adalah kematian dalam mempertahankan diri, membela majikan, menegakkan keadilan, dan penebusan rasa malu atau rasa bersalah (Wulandari, 2006: 15). Seppuku adalah ekspresi kematian yang menyiratkan watak samurai. Dengan demikian tradisi seppuku juga diperkirakan sudah ada sejak zaman Kamakura dan terus berkembang hingga zaman Edo (tahun 1603 sampai dengan tahun1867).

Seppuku yang paling awal dilakukan oleh salah seorang samurai dari keluarga Minamoto, yaitu Minamoto No Yorimasa pada sekitar tahun 1180. Minamoto No Yorimasa melakukan seppuku setelah pertempuran antara keluarga Minamooto dengan keluarga Taira. Dalam pertempuran ini Minamoto No Yorimasa sudah memperkirakan, bahwa kelompoknya akan kalah. Untuk menghindari musuh menangkap dan menyiksanya, ia memilih melakukan seppuku. Setelah peristiwa tersebut, seppuku menjadi bagian dari etika bushido (http://jcul. com/tradisi-bunuh-diri-dijepang/).

Seppuku mencerminkan kepribadian bangsa Jepang yang memiliki keberanian menghadapi resiko dan berani mempertanggungjawabkan kesalahan, kekurangan dan kelemahan diri (Benedict,1982: 172). Untuk menghindari kondisi yang akan mempermalukan diri sendiri maupun dipermalukan orang lain maka seorang samurai memilih jalan kehormatan dengan seppuku. Keberanian dan kesetiaan membuat kehormatan dan kualitas nilai seorang samurai mencapai taraf kesempurnaan.

Karena prinsip utama dari seppuku adalah untuk mengembalikan atau melindungi kehormatan samurai, maka mereka yang tidak termasuk dalam golongan samurai tidak diharapkan melakukan seppuku. Secara umum jika seorang Samurai akan melakukan seppuku, maka harus seijin atasannya yaitu daimyo atau shogun.

\section{2) Macam dan Kategori Seppuku}

Seward (1995 : 21) menyebutkan, bahwa ada beberapa jenis dan macam seppuku yang dilakukan oleh samurai serta makna yang melatarbelakanginya, yaitu:

a. Junshi atau ada yang menyebut chugibara dan oibara, yaitu seppuku yang dilakukan sebagai bentuk kesetiaan bawahan atau anggota keluarga terhadap atasan (majikan) atau tokoh panutannya yang meninggal dunia.

b. Kanshi, yaitu seppuku yang dilakukan sebagai protes terhadap atasan yang melakukan kesalahan atau kesewenang-wenangan. Sebenarnya 
samurai yang melakukan kanshi bukan berarti tidak setia kepada atasannya, tetapi ia berusaha mengekspresikan kesetiaannya dengan cara mengingatkan atasan atau majikannya, bahwa apa yang dilakukan membawa dampak buruk pada nasib seseorang dan diharapkan tidak terulang lagi.

c. Sukotsu shi, yaitu seppuku yang dilakukan untuk menebus kesalahan atau kesewenang-wenangan yang telah dilakukan. Seorang panglima perang yang menyesal terhadap prajurit (militer bawahannya) yang kalah dan gugur dalam perang dan terhadap keluarga yang ditinggalkan. Sukotsu shi juga dilakukan setika seorang samurai membela nama keluarga dan ketika ia akan ditangkap oleh musuh.

d.Munen-bara, yaitu seppuku yang dilakukan karena kemarahan. Munenbara dilakukan seorang samurai untuk membuktikan kesungguhan, kebenaran dan kejujuran terhadap ketidakbenaran sesuatu yang dituduhkan kepadanya, seperti tuduhan penghianatan, ketidakjujuran, ketidaksetiaan dan sebagainya.

e. Jigai, yaitu seppuku yang dilakukan oleh wanita karena tidak mampu menanggung malu atau aib. Selain itu bisa juga dilakukan oleh istri samurai sebagai ungkapan cinta kepada suaminya yang telah melakukan seppuku. Jigai juga sering dilakukan istri dari para samurai yang kalah perang.

Teknik seppuku dilakukan dengan dua cara yaitu ichimonji dan jumonji. Ichimonji adalah merobek perut dengan jalan menusukkan pedang ke perut bagian kiri, lalu menariknya ke sisi kanan. Jumonji yaitu menusukkan pedang ke ulu hati, kemudian menariknya ke bawah sampai ke pusar.

Senjata yang digunakan oleh samurai ketika melakukan seppuku adalah berbagai jenis pedang yaitu tachi (pedang panjang), wakizashi (pedang pendek) atau tanto (pisau). Pedang-pedang ini digunakan untuk merobek perut secara horizontal dan memotong ususnya.

Dalam praktiknya seppuku dilakukan atas 2 hal, yaitu seppuku yang direncanakan dan seppuku sebagai hukuman. Seppuku yang direncanakan biasanya dilakukan di depan penonton. Seppuku yang direncanakan dilakukan dengan persiapan-persiapan, yang tahapannya sebagai berikut :

- Seppuku diawali dengan ritual mandi oleh samurai. Ia kemudian berpakaian kimono putih dan kemudian makan dengan menu kegemarannya. Setelah makan, samurai duduk di tempat yang telah disiapkan dengan posisi seiza (posisi duduk di atas tumit)

- Sebuah gelas sake, setumpuk kertas washi (kertas dari kulit kayu), alat tulis, wakizashi (pedang pendek untuk merobek perut) dan tanto (pisau untuk mengeluarkan isi perut) diletakkan di meja kayu di depan samurai pelaku seppuku.

- Kemudian samurai pelaku seppuku akan meminum sake dua kali, masingmasing dua tegukan. Satu tegukan untuk keserakahan, tiga tegukan lainnya untuk keraguan. Total empat tegukan, atau 'shi'(empat dalam bahasa Jepang), melambangkan kematian. Setelah itu dia akan menulis wasiat terakhir atau menulis puisi kematian dengan tenang dan tanpa peduli bahwa dia akan mati.

- Tahap berikutnya adalah pelaksanaan seppuku oleh samurai. Ia didampingi oleh Kaishakunin, yang bertugas memenggal kepalanya (kaishaku) setelah ia selesai memotong perutnya. Untuk mempercepat kematian dan supaya samurai pelaku seppuku tidak terlalu lama menderita kesakitan, Kaishakunin dengan menggunakan katana (pedang panjang) memenggal kepala samurai tanpa memutuskannya, agar kepala samurai tidak lepas dan 
jatuh. Yang bertindak sebagai Kaishakunin dapat ditunjuk oleh pemerintah Shogun atau teman dekat samurai pelaku seppuku.

- Tahap akhir dari seppuku adalah pembersihan tempat seppuku. Peralatan yang dipakai dalam seppuku seperti meja dan pedang akan dibuang karena dianggap telah tercemar oleh kematian.

- Setelah seppuku selesai maka jenasah samurai dikembalikan kepada keluarga atau dimakamkan di lingkungan kuil Budha atau Shinto.

Seppuku yang dilakukan atas kehendak sendiri dengan kesadaran dan sukarela dianggap sebagai sikap yang terpuji seorang samurai terhadap majikan/pimpinannya dan pihak yang dirugikan. Seppuku yang dilakukan secara sukarela dianggap sebagai kematian terhormat bagi keluarga pelaku seppuku dan memungkinkan pelaku seppuku mendapat penghargaan atas jasanya selama hidup.

Seppuku sebagai hukuman mati dilakukan untuk mempermalukan samurai yang telah melakukan tindakan kriminal seperti pemerkosaan, perampokan, korupsi dan pengkhianatan. Hukuman

seppuku dianggap sebagai hukuman yang lebih baik bagi samurai pelaku kriminal dibandingkan dengan hukuman lain. Samurai yang melakukan tindak kriminal diberi kesempatan untuk mengakhiri hidupnya dan mati dengan cara terhormat melalui Seppuku.

Seppuku untuk hukuman mati, tidak dengan sendirinya bisa membebaskan dan memaafkan samurai pelaku kriminal beserta keluarganya dari sanksi sosial masyarakat. Sanksi soaial ini tergantung dari berat atau tidaknya kejahatan yang dilakukan oleh samurai. Harta benda hasil kejahatan dapat disita dan keluarga mendapatkan sanksi sosial berupa pencabutan posisi atau jabatannya atau dapat juga ia dijual sebagai budak sampai dieksekusi. Ada perkecualian, yaitu bila samurai yang dijatuhi hukuman diampuni dan dimaafkan oleh keluarga pihak yang dirugikan.

Hukuman mati dalam bentuk seppuku dihapus pada tahun 1873 melalui peraturan yang dibuat kaisar Jepang, karena hukuman mati dengan seppuku tidak mengurangi jumlah kriminakitas yang dilakukan oleh samurai. Selain itu di era Meiji golongan samurai telah dihapuskan.

\section{3) Simbolisme dalam Seppuku}

Sebagai tradisi seppuku penuh makna simbolik yang perlu dipahami, sehingga seppuku bukan hanya bunuh diri biasa. Ada nilai-nilai luhur yang terkandung di dalamnya.

\section{a. Perut}

Dalam seppuku ada bagian-bagian tubuh yang dilukai, yaitu perut. Perut dalam tradisi Jepang dianggap penting karena sebagai pusat segala emosi dan kejiwaan. Perut merupakan simpul energi fisik dan aktivitas pada tubuh manusia, mulai dari seksualitas, pernafasan, kesadaran, semangat dan otak (Batubara, Y.A, 2008 : 71)

Perkembangan pemaknaan perut mendapat pengaruh dari budaya di luar Jepang, yaitu Tao dari Cina. Dalam ajaran Tao kemampuan beradaptasi dan menyeimbangkan kehidupam dengan alam semesta adalah melalui "kekosongan". "Kekosongan" dapat dicapai melalui meditasi, yaitu memusatkan pikiran untuk mencapai harmoni dengan kekuatan alam semesta dan mengabaikan rangsanganrangsangan indrawi. Dalam melakukan meditasi, seseorang memfokuskan kekuatannya pada perut untuk mencapai kedalaman kesadaran dan eksistensinya. Ia harus mengabaikan rangsangan pada indra lainnya.

Dalam pandangan Tao, seppuku dengan menusuk dan memotong perut, bermakna bukan hanya menghabisi nyawa 
secara fisik dan mental, tetapi juga mematikan kesadaran tertinggi seorang manusia (King, $1993: 11-12$ ).

\section{b. Senjata Katana, Wakisashi, Tanto}

Katana adalah pedang panjang yang digunakan para samurai dalam peperangan maupun seppuku. Menurut sejarah Jepang yang terekan dalam Kojiki dan Nihongi, pada masa awal sejarah Jepang, Jepang diperintah oleh keturunan Amaterasu $\mathrm{O}$ Mikami (Dewi Matahari), yaitu Ninigi-NoMikoto. Sebagai lambang kekuasaannya Ninigi-No-Mikoto dibekali dengan tiga benda suci, yaitu kalung, kaca (cermin) dan pedang (Suryohadiprojo,1981 : 10). Pedang panjang sebagai benda suci disebut sebagai katana.

Katana menjadi simbol kekuatan dalam menegakkan keadilan dan kebenaran serta menjamin kedamaian. Katana yang digunakan oleh Kaishakunin dalam seppuku menunjukkan makna yang sama yaitu menegakkan keadilan dan lambang keberanian. Selain itu katana melambangkan kekuatan kami, yang dapat mengantar samurai pelaku seppuku menuju kematian terhormat dan diberkati, dan menghindarkan samurai dari kematian yang dipengaruhi oleh kekuatan jahat.

Wakizashi adalah pedang pendek yang menyerupai katana dengan panjang antara 30 sampai 60 sentimeter. Wakizashi sering dikenakan bersama katana. Apabila dikenakan bersama, pasangan pedang ini disebut daisho. "Dai" artinya besar untuk menyebut katana, dan "sho" artinya kecil untuk menyebut wakizashi (https://id.wikipedia.org/wiki/Wakizashi).

Wakizashi lebih tipis dan tajam dibandingkan dengan katana. Dengan demikian penggunaan wakizashi lebih efektif daripada katana. Dalam seppuku wakizashi digunakan oleh samurai untuk memotong perutnya.

Tanto adalah sejenis belati, yang bermata tunggal atau ganda dan panjangnya berkisar antara 15 hingga 30 $\mathrm{cm}$. Menurut tradisi, tanto digunakan sebagai senjata untuk menikam, dan biasanya berbentuk lurus, bukan melengkung (https:// japanesestation.com/mengenal-7-jenispedang-jepang-yang-sering-digunakanpara ksatria). Tanto dalam seppuku digunakan oleh samurai untuk memotong dan mengeluarkan ususnya sebagai tanda keberanian dan tanggunggung jawab moral atas kesalahan dalam tugas, kesetiaan dn rasa hormat kepada atasan.

\section{c. Warna Putih}

Dalam seppuku ada beberapa perlengkapan yang berwarna putih seperti kimono yang digunakan oleh samurai pelaku seppuku dan Kaishakunin, pasir, tirai dan sebagainya. Warna putih dalam budaya Jepang dianggap sebagai warna yang melambangkan kedewaan, ketuhanan, kesucian, sakral.

Samurai pelaku seppuku mengenakan kimono warna putih, yang melambangkan kesederhanaan, kesucian , kemurnian jiwa dalam menghadapi kematian.

\section{d. Shugyo-mon dan Nehan-mon}

Shugyo-mon dan Nehan-mon adalah dua gerbang yang dibuat di tempat upacara seppuku. Shugyo-mon dan Nehan-mon terbuat dari 2 batang kayu yang dihubungkan dengan kayu lain di atasnya. Bentuknya seperti torii, yaitu gerbang khas kuil Shinto. Kedua nama gerbang ini erat kaitannya dengan budaya Budha.

Shugyo-mon ada di sebelah utara, yaitu arah masuk samurai pelaku seppuku. Shugyo-mon memiliki makna sebagai gerbang pertapa. Samurai duduk di atas tatami menghadap arah utara (menghadap Shugyo-mon). Penamaan gerbang Shugyomon ini memiliki makna, bahwa samurai pelaku seppuku sama derajatnya dengan pertapa yang tinggi derajat moralitasnya. Seppuku dalam tradisi Budhis adalah bentuk latihan jiwa untuk mencapai tingkat moralitas dan derajat kebatinan yang 
Kiryoku, Volume 3 No 42019

e-ISSN: 2581-0960 p-ISSN: 2599-0497

Tersedia online di http://ejournal.undip.ac.id/index.php/kiryoku

tinggi. Seppuku dalam tradisi Budha Zen bukan dianggap sebagai karma buruk, tetapi dianggap sebagai upaya pengendalian diri. Samurai pelaku seppuku dan Kaishakunin memainkan peran penting karena memiliki kesadaran spiritual yang tinggi dan mampu mengendalikan emosi dalam ritual seppuku.

Nehan-mon terletak di sebelah selatan, yang merupakan jalan masuk Kaishakunin. Makna nehan-mon adalah gerbang nirwana, yang menunjukkan bahwa Kaishakunin juga telah melakukan karma yang baik, yaitu membantu samurai pelaku seppuku segera mengakhiri penderitaannya. Kaishakunin biasanya duduk di samping samurai pelaku seppuku.

Penempatan Shugyo-mon dan Nehan-mon juga ada kaitannya dengan konsep feng shui. Arah utara dalam feng shui dianggap sebagai arah yang mengandung unsur-unsur yin yaitu arah yang negatif, pasif, dingin, penerima dan arah kematian. Arah selatan dipandang sebagai arah yang mengandung unsurunsur yang yaitu arah yang dinamis aktif, hangat, bergairah, kreatif.

Dapat dikatakan bahwa ritual seppuku mengandung unsur-unsur yang kompleks. Bentuk shugyo-mon dan Nehanmon dipengaruhi oleh budaya Shinto, penamaannya mengandung unsur-unsur budaya Budha dan peletakannya mengandung unsur budaya Tao dan Konfusius.

\section{e. Puisi}

Membuat puisi merupakan salah satu kebiasaan yang dilakukan seorang samurai sebelum melakukan seppuku, baik seppuku spontan atau seppuku yang direncanakan. Di Jepang sejak dari awal terbentuknya golongan samurai, sudah ada kebiasaan membuat puisi. Membuat puisi merupakan suatu kondisi untuk meperlihatkan tingkat intelektual dan kepekaan seorang samurai terhadap kondisi sosial masyarakat.

Puisi-puisi kematian biasanya merupakan kelanjutan dari puisi-puisi yang sudah dibuat semasa hidup samurai dan diselesaikan ketika ia akan melakukan seppuku. Dalam upacara seppuku, membuat puisi merupakan salah satu tahapan yang harus dilakukan seorang samurai pelaku seppuku.

Puisi-puisi yang dibuat samurai pada masa awal mengungkapkan kematian secara tegas. Pada masa-masa kemudian puisi tidak lagi mengungkapkan kematian secara tegas, tetapi diungkapkan secara simbolik, seperti ungkapan tentang bunga sakura yang layu, langit mendung, musim gugur, senja, matahari meredup, angin bertiup di malam hari dan sebagainya, yang menyiratkan kesedihan dan kepedihan.

Selain dengan puisi ungkapan perasaan samurai pelaku seppuku disampaikan pada sahabat atau kerabat dekatnya tentang kerisauannya mengambil keputusan melakukan seppuku, tanggung jawab, rasa bersalah, alasan dan pandangan mereka terhadap seppuku. Karena seppuku adalah tanggung jawab dan otoritas yang sifatnya pribadi, maka teman atau kerabat tidak memiliki otoritas untuk melarang atau menghalangi seorang samurai melakukan seppuku.

\section{4) Bunuh Diri (Jisatsu) di Zaman Modern}

Setelah Restorasi Meiji berlangsung dan Jepang bertransformasi menjadi negara modern. Lambat laun tradisi seppuku mulai dihapus seiring dengan dihapuskannya golongan samurai. Walaupun seppuku sudah dihapus, dan eksistensi golongan samurai lenyap, tidak membuat pelaku bunuh diri menghilang. Bunuh diri di luar seppuku yang terjadi di masa Perang Dunia I dan Perang Dunia II dapat kita lihat dalam bentuk kamikaze. Kamikaze, yang artinya "Angin Dewa" adalah tindakan para pilot pesawat tempur Jepang dalam Perang Dunia I dan perang Dunia II, yang ketika terdesak musuh kemudian menjatuhkan atau menabrakkan pesawatnya pada obyek strategis militer musuh. Kamikaze merupakan bentuk 
pengorbanan dan kesetiaan para anggota militer Jepang terhadap negara dan kaisarnya (Wibawarta, $2006: 60$ ).

Bunuh diri yang terjadi di zaman modern sekarang ini tidak dapat disebut sebagai seppuku, karena nilai religius dan moralitasnya sudah hilang. Bunuh diri yang dilakukan oleh orang-orang Jepang di era modern ini adalah bunuh diri biasa, yang disebut jisatsu.

Jumlah pelaku bunuh diri di Jepang yang semakin banyak dilaporkan oleh CNN yaitu bahwa antara tahun 2016 sampai dengan tahun 2018, telah terjadi 250 kasus bunuh diri yang dilakukan oleh anak-anak usia Sekolah Dasar sampai dengan remaja murid Sekolah Menengah Atas. Badan Kebijakan Nasional Jepang menyatakan, bahwa total kasus bunuh diri di Jepang mencapai 21.321 pada 2017 (https: // internasional . kompas. com/read/ 2018/ 11/06/12440551/angka-bunuh-dirianak-di-jepang-tertinggi-dalam-30-tahunterakhir? Page $=$ all). Pihak-pihak yang berkepentingan menangani masalah tersebut belum menemukan alasan anakanak ini melakukan bunuh diri.

Dari penyelidikan yang dilakukan terhadap remaja dan anak-anak yang bunuh diri, diperkirakan penyebab bunuh diri di antaranya adalah :

- Masalah yang dihadapi anak atau remaja di sekolah. Biasanya mereka mengalami bullying and harassment (intimidasi dan pelecehan) atau mereka tidak dapat mengikuti pelajaran dengan baik

- Masalah dalam rumah atau keluarga, yang tidak dapat mereka selesaikan, seperti pertengkaran antara ayah dan ibu atau antaranggota keluarga yang lain.

- Masalah asmara yang menyebabkan mereka patah hati.

- Merasa sendiri, tidak ada teman untuk berbagi dan mencurahkan perasaan sedih maupun gembira.

- Masalah keuangan keluarga yang minim sehingga tidak dapat memenuhi semua kebutuhannya dan penyebab lainnya.

Dari kasus-kasus bunuh diri yang dilakukan oleh orang-orang dewasa sampai orang tua, penyebabnya adalah :

- Pekerjaan yang tidak memberikan kenyamanan. Banyak orang yang kurang cocok dengan pekerjaannya sehingga mengalami tekanan batin dan stres yang tinggi. Ketidakmampuan mengatasi dan memecahkan masalah di tempat kerja, menyebabkan depresi dan mereka mudah mengambil keputusan bunuh diri.

- Masalah ekonomi, termasuk pemutusan hubungan kerja juga menjadi pemicu bunuh diri. Pemutusan hubungan kerja menyebabkan stres, karena ada orang yang sulit menemukan pekerjaan pengganti. Ada juga yang karena usia sudah lanjut, bila berganti pekerjaan sulit menyesuaikan diri dengan pekerjaan yang baru.

- Kesalahan dalam melakukan manajemen pekerjaan sering kali juga memicu stres, sehingga orang putus asa karena tidak dapat memperbaiki kesalahanya. Kadang juga dipicu rasa malu atas ketidakmampuannya melakukan pekerjaannnya.

- Kasus korupsi menjadi salah satu penyebab bunuh diri, karena pelaku korupsi tidak sanggup menanggung malu dan aib serta tuntutan tanggung jawab yang berat. Untuk menghidari masalah-masalah ini biasanya orang mengambil jalan pintas bunuh diri.

- Masalah kesehatan dan penyakit juga menjadi beban yang berat, terutama bagi orang usia lanjut. Masalah kesehatan semakin berat ketika tidak ada keluarga yang merawat atau tidak ada yang menemani. Beban ini seringkali memicu keinginan bunuh diri.

- Kesepian menjadi salah satu sebab tekanan dan stres. Di zaman modern yang serba cepat membuat orang tidak 
mempunyai banyak waktu untuk memberikan perhatian kepada keluarga. Masing-masing anggota keluarga sibuk melakukan aktivitasnya masing-masing, yang menyebabkan orang tua (ayah dan ibu) kesepian. Hidup sendiri yang menimbulkan perasaan tidak berguna menjadi salah satu penyebab munculnya niat untuk bunuh diri.

Dari beberapa penyebab bunuh diri yang dapat ketahui, ada perbedaan antara seppuku dengan bunuh diri (jisatsu) di zaman sekarang, yaitu pada bentuk dan alasan serta tujuan bunuh diri. Pada zaman feodal seppuku dilakukan dengan alasan dan sebagai bentuk loyalitas terhadap majikan atau atasan. Alasan dan tujuan jisatsu di zaman modern ini bergeser menjadi bentuk penyelesaian masalah dan pelarian dari perasaan depresi. Selain itu seppuku dilakukan dengan tahapan-tahapan upacara dan ritual, sedangkan jisatsu zaman sekarang dilakukan mandiri dan kadang tanpa persiapan. Perbedaan yang lain yaitu unsur-unsur religius dalam seppuku masih sangat kental dibandingkan dengan jisatsu, yang nilai individualnya tinggi.

Kondisi ini tentu sangat memprihatinkan bagi pemerintah Jepang. Di satu sisi Jepang sebagai negara maju sudah mencapai tingkat ekonomi yang tinggi, tetapi mengalami masalah sosial yang cukup drastis, yaitu masalah bunuh diri yang sangat memprihatinkan.

\section{SIMPULAN}

Nilai-nilai luhur bangsa Jepang yang lahir di zaman feodal di era Kamakura, yaitu nilai-nilai bushido yang menjadi acuan para samurai, saat ini mulai terkikis, terutama nilai-nilai yang terkandung dalam seppuku. Pada zaman modern ini semangat seppuku hendaknya dipupuk dalam bentuk lain, yaitu berupa tanggung jawab, disiplim, solidaritas dan penghormatan yang tinggi kepada atasan, kepada kaisar dan negara dan bangsa. Penghormatan dan kesetiaan tidak harus diekspresikan dalam bentuk pengorbanan nyawa, tetapi pengabdian penuh makna dalam bentuk kerja keras, membina solidaritas dan kepedulian sosial, menciptakan persaudaraan dan ikatan nasionalisme yang kuat.

Nilai-nilai bushido yang masih relevan dengan zaman modern sekarang ini patut dijaga, dipelihara dan diamalkan, seperti gi ( integritas), $\mathrm{y} u$ (keberanian), jin (murah hati), rei (hormat dan santun kepada orang lain), makoto-shin (kejujuran dan ketulusan), meiyo (menjaga nama baik dan kehormatan), chugo (kesetiaan pada pemimpin), tei (peduli). Bila nilai-nilai bushido ini dikembangkan, dapat menjadi sarana pendidikan yang dapat mengurangi jumlah pelaku bunuh diri, baik pelaku bunuh diri anak-anak, remaja, orang dewasa maupun orang tua.

Antara seppuku di masa lalu dengan jisatsu di masa kini tidak ada korelasi yang jelas, karena para pelaku jisatsu tidak memahami nilai-nilai moral yang terkandung dalam seppuku. Mereka hanya memahami, bahwa masyarakat Jepang memiliki tradisi bunuh diri, tanpa melihat latar belakang budaya yang mendasarinya.

Banyak penyebab yang menjadikan orang berniat dan melakukan bunuh diri. Untuk mengurangi jumlah pelaku jisatsu, pemerintah Jepang harus berupaya mencari metode yang tepat. Upaya yang telah dirintis pemerintah Jepang yaitu pada tahun 2002 membentuk organisasi yang bergerak di bidang kesehatan (fisik dan non fisik atau kesehatan jiwa) patut mendapat apresiasi. Selain itu juga dilakukan pendampingan dan konsultan untuk orang-orang yang rentan terhadap depresi.

Program pemerintah Jepang ini mendapat sambutan yang baik dari masyarakat, sebab masalah jisatsu bukan lagi menjadi masalah individu tetapi sudah menjadi masalah nasional yang perlu penanganan serius. 


\section{REFERENSI}

Batubara, Y.A (2008). Seppuku : Telaah Religiositas dalam Upacara Bunuh Diri Ala Jepang. Skripsi. Jakarta : Fakultas Ushuluddin dan Filsafat Universitas Islam Negeri Syarif Hidayatullah.

Bellah, R.N. (1992). Religi Tokugawa Akar-akar Budaya Jepang. Jakarta : PT Gramedia Pusaka Utama.

Benedict, R. (1982). Pedang Samurai dan Bunga Seruni : Pola-pola Kebudayaan Jepang. Jakarta: Sinar Harapan.

Bryant, A.J. (2008). Samurai 1550-1600. Great Britain: Osprey Publishing.

Durkheim, E (1979). Suicide: A Study in Sociology.London ; Routledge Kegan \& Paul

Goottschalk, L (1975). Mengerti Sejarah: Pengantar Metode Sejarah. Jakarta: Yayasan Penerbit Universitas Indonesia.

King, W. L. (1993). Zen and The way of the Sword. New York : Oxford University Press.

Mattulada (1979). Pedang dan Sempoa.Tanpa penerbit

Miles, M. B \& Huberman, A. M. (1992). Analisis

Data

Kualitatif. .Jakarta: UI-Press

Nitobe, I.(2001). Bushido : The Soul of Japan. Boston : Turtle Puplishing.

Seward, J. (1995). Hara Kiri Bunuh Diri Ala Jepang. Jakarta : Penerbit Ghalia Indonesia.

Suliyati, T. "Bushido Pada Masyarakat Jepang : Masa Lalu dan Masa Kini," IZUMI, vol. 1, no. 1, Jan. 2013.

Suryohadiprojo, S. (1982). Manusia dan Masyarakat Jepang dalam
Perjoangan Hidup. Jakarta : UI-Pres.

Wibawarta, B. (2006). Bushido dalam Masyarakat Jepang Modern. Wacana Vol. 8 no. 1, April 2006 (54-66)

Wulandari, G. (2006) .Analisa Kesetiaan Pada Tokoh-Tokoh Samurai dalam Komik Samurai X Karya Nobihiro Watsuki.Skripsi. Medan: Fakultas Sastra USU

\section{Sumber-sumber dari internet :}

Hendara, Adrian. 2018. Mengenal 7 Jenis Pedang Jepang Yang Sering Digunakan Para Ksatria diakses melalui

https://japanesestation.com/men genal-7-jenis-pedang-jepangyang-sering-digunakan-paraksatria/ tanggal 26 November 2019.

Rinaldo, 2017.Tradisi Bunuh Diri Jepang, dari Seppuku hingga Ningen Gyorai diakses melalui :http://jcul. com/tradisibunuh-diri-di-jepang/), tanggal 12 November 2019

Utomo, Ardi Priyatno (editor Kompas.com), 2018. Angka Bunuh Diri Anak di Jepang Tertinggi dalam 30 Tahun Terakhir diakses melalui: https: $/ /$ internasional. kompas. com $/ \mathrm{read} / 2018 /$ 11/06/12440551/angka-bunuhdiri-anak-di-jepang-tertinggidalam-30-tahun-terakhir? Page $=$ all), tanggal 25 November 2019

Wikipedia. Wakizashi diakses melalui https://id.wikipedia.org/wiki/W akizashi pada tanggal 30 Oktober 2019 